Лариса Левицька,

Національний університет оборони України імені Івана Черняховського, м. Київ

ORCID ID 0000-0001-6575-9964

DOI: $10.33099 / 2617-1775 / 2020-02 / 166-173$

\title{
ІМПЛЕМЕНТАЦІЯ РЕЗУЛЬТАТІВ НАУКОВИХ ДОСЛІДЖЕНЬ У ВИЩИХ ВІЙСЬКОВИХ НАВЧАЛЬНИХ ЗАКЛАДАХ: ПІДХОДИ ТА СПОСОБИ ОПТИМІЗАЦІї
}

У статті розглянуто існуючі підходи та способи імплементації результатів наукових досліджень в освітню діяльність вищих військових навчальних закладів, узагальнено вітчизняний та зарубіжний досвід освоєння, використання та комериіалізачії наукових результатів, визначено зв'язок прочесу імплементачії результатів наукових досліджень $в$ освітню діяльність та потребами, щзо визначають рівень підготовки військових фахівиів до практичної діяльності у військах (силах) та органах військового управління.

Ключові слова: військові фахівці; вищі військові навчальні заклади; імплементація; комериіалізація; наукові дослідження; підходи; способи оптимізації.

Постановка проблеми. В умовах модернізації національної системи військової освіти, використання досягнень науки в практиці освітньої діяльності вищих військових навчальних закладів (ВВН3) є однією з важливих та необхідних умов підготовки висококваліфікованих військових фахівців. Однак сьогоднішній стан системи військової освіти, іiі зв'язок не тільки з фундаментальною наукою, але й 3 конкретною практичною діяльністю військових фахівців, пов'язаною 3 виконанням службових обов'язків у військах (силах) та органах військового управління, залишається у межах суттєвого розриву між проведенням наукових досліджень і справдженням їх результатів в освітній процес ВВНЗ.

Наприклад, оцінюючи загальний рівень інформатизації аналітичної діяльності органів військового управління в сучасній Україні, дослідники звертають увагу на те, що у цій сфері $є$ нагальною потреба щодо вирішення проблеми створення чи суттєвої модернізації, перш за все, органів військового управління, приведення у відповідність потреб в інформації зі здатністю цю інформацію обробляти та якістю аналітичного забезпечення. Зокрема, Р. Бакуменко вважає, що “недостатнє оснащення органів військового управління програмно-апаратними засобами, відсутність скоординованої системи показників i затверджених методик їх розрахунку не дозволяють прозоро відслідкувати узгодженість і несуперечливість цілей, що ставляться на всіх рівнях управління, контролювати їх додержання та приймати рішення щодо забезпечення їх досягнення" [2, с. 13]. У даному випадку очевидною є суперечність, що виникає на двох основних етапах - підготовки військових фахівців та їх практичної діяльності, - характеризуючи якість отриманої освіти на всіх рівнях щодо іï відповідності конкретним умовам вирішення завдань. Фактично йдеться про те, що можливості сучасної системи військової освіти потребують суттєвого 
розширення, у тому числі й за рахунок активної імплементації результатів сучасних наукових досліджень в освітній процес ВВНЗ.

Метою статті $\epsilon$ аналіз підходів та способів оптимізації процесу імплементації результатів наукових досліджень у діяльність ВВНЗ у зв’язку з підвищенням оцінки якості підготовки військових фахівців.

Методи дослідження теоретичні, аналітичні, 3 використанням наукових джерел зі створення i функціонування інформаційно-аналітичних систем управління.

Аналіз останніх досліджень і публікацій. Питанням впровадження та реалізації результатів наукових досліджень в освітній діяльності ВН3, ВВН3 та ВНП ЗВО в різних аспектах приділяли увагу А. Алімпієв, Т. Боголіб, Д. М. Гніденко, Гриб, Б. Демідов, Р. Дзюбчук, О. Ільїн, Г. Капосльоз, А Кучерявий, О. Сафронов та інші науковці. Переважна більшість сучасних досліджень звертає увагу на наявність певних проблем, які необхідно вирішити для підвищення якості освітнього процесу у ВВН3 та ефективності функціонування системи наукових досліджень у ВВНЗ. Також увага приділяється практичній складовій діяльності військових фахівців як виразника якості отриманої військової освіти та підготовки для служби у військах (силах) та органах військового управління.

Виклад основного матеріалу. Одним із визнаних та досліджених шляхів сприяння реалізації наукових розробок в освітній діяльності ВВНЗ є інтеграція вищої освіти, науки та бізнесу. Зростання частки наукомістких продуктів i технологій уможливлює комерціалізацію використання результатів наукових розробок ВВН3, сприяючи розвитку прикладної науки за рахунок [7]:

- залучення капіталу комерційних структур (шляхом реалізації наукових розробок, обслуговування бізнес-проектів) 3 метою створення університетом власних навчальної бази, виробництва (бізнес-інкубаторів, технопарків);

- можливості проходження студентами практики на створених виробництвах так і в компаніях-донорах;

- $\quad$ реалізація програм підтримки підприємств малого наукомісткого бізнесу шляхом реалізації системи його “інкубаціі”, в рамках якої перспективним компаніям надаються стартові ресурси у вигляді приміщення під офіс і права користування лабораторними площами та обладнанням інкубатора бізнесу створюють умови працевлаштування студентів після навчання.

У цьому контексті важливо враховувати досвід зарубіжних країн, проаналізований у працях [3; 7], адже узагальнення не тільки вітчизняного, але й зарубіжного досвіду освоєння та використання наукових результатів у навчальних закладах та органах управління освітою дозволяє визначити підходи до імплементації наукових результатів в освітню діяльність ВВНЗ. Так, у США підтримується тенденція до стимулювання установлення більш тісних зв'язків між фірмами високотехнологічних галузей i державними дослідницькими університетами для того, щоб створювати центри нових технологій. Формою організації такої співпраці слугують так звані “науково-технологічні парки” свого роду інкубатори наукомісткого бізнесу i практична основа наукової 
діяльності університетів. Діють венчурні та посівні фонди, приватні інвестори (“бізнес-ангели”), технопарки і бізнес-інкубатори, розвивається інноваційний консалтинг.

Значний досвід з комерціалізації наукової діяльності ВНЗ існує в Ізраїлі, де університети займаються широкомасштабною науково-дослідною роботою i сприяють розвитку науки. В Ізраїлі вперше у світі почали приєднувати наукомісткі промислові проекти до університетських програм. Крім того, при університетах (часто спільно з місцевими та іноземними компаніями) на основі їх технічних розробок створюються дочірні промислові фірми, які займаються комерційною реалізацією продукції. Кількість патентів, отриманих ізраїльськими університетами, - один 3 показників ефективності співпраці університетської науки та промисловості.

Звертаючись до досвіду зарубіжних країн у сфері підвищення ефективності використання результатів наукових досліджень, їх імплементації в освітній процес , можна побачити, що наразі практикуються різні напрями, які об'єднуються загальним підходом, спрямованим на інтенсифікацію процесу імплементації результатів наукових досліджень не тільки у напрямі комерціалізації наукової діяльності, але й у сфері оцінки якості освітнього процесу ВНЗ, зокрема результатів освіти. Дійсно, сьогодні на рівні держави вирішується питання статусу дослідницьких університетів, які згодом об'єднуються в асоціацію, до неї входять також галузеві міністерства та відомства, представники великих бізнес-корпорацій, уряд, інститути громадянського суспільства. Також визначаються пріоритетні інноваційні проекти, джерела фінансування. На конкурсній основі дослідницькі університети отримують такі наукові завдання, виконання яких забезпечує реалізацію інноваційних проектів та гранти на наукові розробки. Проте 3 точки зору оцінки якості та ефективності імплементації результатів наукових досліджень в освітній процес ВВНЗ, оцінки якості підготовки військових фахівців 3 урахуванням сучасного досвіду та результатів розвитку науки, формування зворотного зв'язку між системою військової освіти, військами та органами військового управління актуальності набувають конкретні підходи та способи такої імплементації.

3 огляду на вирішення цього питання у деяких дослідженнях запропоновано застосовувати спосіб ієрархічного структурування інформаційного простору начального процесу, який реалізує такі базові принципи, як [4]:

- прикладні програми, що відокремлені від даних;

- стандартизовані структури даних і інтерфейс доступу до них;

- дані про процеси і ресурси не дубльовані, число помилок в них мінімізується, забезпечується повнота і цілісність інформації;

- прикладні засоби роботи з даними $\epsilon$, як правило, типові рішення різних виробників, що забезпечує можливість подальшого розвитку інформаційного середовища.

3 огляду на перспективи оцінки ефективності імплементації результатів наукових досліджень у ВВН3, а також розширення контексту оцінки освітнього процесу, зокрема процесу підготовки військових фахівців, наведені елементи 
способу ієрархічного структурування інформаційного простору навчального процесу мають певні переваги порівняно з поширеними способами і методами (наприклад, метод експертних оцінок, педагогічного експерименту тощо). Ці переваги полягають в об'єктивації процесу оцінки, адже за наведеним способом структурування інформаційного простору інформаційні об'єкти, що містять дані про характеристики виробів, виробниче середовище тощо відносяться і до системи менеджменту якості [4, с. 39], тобто дійсно уможливлюється підвищення якості та оперативності інформаційної підтримки процесу навчання, а також процесу імплементації результатів наукових досліджень в освітній діяльності ВВН3, яка є значною мірою стандартизованою.

Варто погодитись 3 думкою дослідників про те, що стандартизація структур даних забезпечує можливість застосування стандартних програмно-технічних рішень для автоматизації процесів підтримки навчального процесу у ВВН3, оскільки у даному випадку очевидним є те, що використання сервіс орієнтованої архітектури програмних систем дозволяє забезпечити реалізацію таких системо утворюючих вимог до інформаційної системи, як відкритість, інтеграція, масштабованість, переносимість [4, с. 39]. Останнє, з точки зору актуального завдання щодо оцінки якості освітнього процесу у ВВН3, а також формування стійкого зворотного зв'язку, який має підтримувати корегування навчання (його структури, змісту тощо) відповідно до потреб конкретної практичної діяльності. У випадку підготовки військових фахівців йдеться, перш за все, про зв’язок між ВВН3 та військами або органами військового управління, які мають безпосередню інформацію щодо якості отриманої військовими фахівцями освіти. У цьому контексті формування єдиного інформаційного простору стає важливим завданням, оскільки “'”'являється можливість не просто зберігати зафіксовані в електронному вигляді результати навчального процесу (оцінки тощо)”, але й простежувати показники ефективності і результативності навчального процесу, забезпечувати високу якість його інформаційної підтримки [4, с. 40]. У даному випадку важливим виявляється те, що структура організації єдиного інформаційного простору за ієрархічним способом спрямована на "автоматизацію отриманого досвіду, в результаті чого 3'являється нова якість управління навчальним процесом", а саме [4, с. 42]:

- $\quad$ 3'являється можливість усунути інформаційний розрив на різних рівнях iєpapxiï;

- з'являється можливість оперативного аналізу показників, що характеризують стан навчального процесу протягом його життєвого циклу;

- вся інформація, що необхідна для управління навчальним процесом на різних рівнях, є доступною в єдиному інформаційному просторі тощо.

Більш того, важливо враховувати, що результативність дослідження значною мірою визначається ступенем реалізації його результатів, тобто впровадженням, яке, як процес, являє собою “передачу виконавцями НДР наукових результатів замовникам для їх освоєння та практичного використання споживачами з метою підвищення ефективності їх роботи" [7, с. 128]. У цьому процесі необхідно звернути увагу на те, що наукові результати НДР перетворюються на продукт 
лише з моменту готовності до використання споживачем (замовником чи іншим суб'єктом), а “обов’язковою умовою отримання ефекту від впровадження $\epsilon$ готовність споживачів застосовувати запропоновані нововведення” [7, с. 128]. Такий підхід дає можливість вказати, що імплементація результатів наукових досліджень може здійснюватися як на заключному етапі виконання НДР, коли впровадження передбачає удосконалення практики, перевірку, уточнення i розвиток теорії та методики, відпрацювання рекомендацій тощо, так і після завершення НДР, що передбачає впровадження відпрацьованих, готових, перевірених результатів. Метою останнього $є$ удосконалення практичної діяльності, що залишається одним з визначних позитивних моментів розвитку науки, у тому числі й наукової діяльності, що здійснюється у ВВНЗ, сприяючи удосконаленню на основі імплементації результатів наукових досліджень в освітній процес ефективності підготовки висококваліфікованих військових фахівців.

Поряд 3 цим залишається актуальним і такий принцип науково-педагогічних досліджень у галузі військової освіти, як практична затребуваність результатів досліджень i можливість їх впровадження в практику освітньої та наукової діяльності ВВН3, коли кінцевий науковий продукт проходить обов’язкову апробацію у ВВНЗ та ВНП ЗВО, в ході якої враховуються їх пропозиції, а результати досліджень надаються споживачу для подальшого впровадження у практичну діяльність [8, с. 149]. При цьому, як справедливо зазначають дослідники, “наукова (науково-технічна) продукція, що створюється в інтересах ВВНЗ під час проведення наукових досліджень, покликана гарантувати якість освітніх послуг, які надає заклад, та відповідність підготовки випускників вимогам сучасних збройних сил" [5, с. 58]. Водночас, пропонуючи перспективну модель організації наукового забезпечення освітньої діяльності ВВН3, більшість досліджень звертає увагу на те, що така модель дає можливість $[1 ; 5 ; 6 ; 9]$ :

- підвищувати наукову кваліфікацію науково-педагогічних працівників;

- покращувати методичне забезпечення освітньої діяльності ВВНЗ;

- удосконалювати науково-дослідну частину навчально-матеріальної бази BBH3;

- зосереджувати основні зусилля наукових i науково-педагогічних працівників ВВНЗ на проведенні наукових досліджень щодо вирішення актуальних для освітньої діяльності ВВНЗ проблем тощо.

Висновки та перспективи подальших досліджень. Сучасна система військової освіти потребує суттєвого розширення, у тому числі й за рахунок активної імплементації результатів сучасних наукових досліджень в освітній процес ВВНЗ. Це дозволить удосконалити підходи до оцінки якості освітнього процесу в цілому та підготовки військових фахівців зокрема поряд iз удосконаленням процесу інформаційного забезпечення проведення наукових досліджень, що виконуються для задоволення потреб Збройних Сил, створюючи можливість ефективної імплементації отриманих результатів наукових досліджень в освітній процес ВВНЗ. Важливим питанням у цьому контексті $\epsilon$ розроблення конкретних методик оцінки, що потребує подальших досліджень. 


\section{ЛІТЕРАТУРА}

1. Алімпієв А. Моделі і методи планування та управління науковими дослідженнями / А. Алімпієв, Д. Гриб, Б. Демідов та ін. // Наука і техніка Повітряних Сил Збройних Сил України. 2014. - № 2(15). - С. 173-176.

2. Бакуменко Р. Інформаційно-аналітичне забезпечення органів військового управління: стан, проблеми та підготовки фахівців / Р. Бакуменко // Військова освіта. - 2019. - № 1(39). - С. 8-16.

3. Боголіб Т. Комерціалізація наукових розробок університетів. Управління економікою: теорія і практика / // “Економіка України”. - 2014. - № 1. - С. 33-50.

4. Гніденко М. Спосіб ієрархічного структурування інформаційного простору начального процесу / М. Гніденко, О. Ільїн // Військова освіта. - 2017. - № 1(35). - С. 38-44.

5. Дзюбчук Р. Місце та роль наукових досліджень у забезпеченні освітньої діяльності вищого військового навчального закладу технічного профілю підготовки / Р. Дзюбчук, Г. Капосльоз, О. Розумний // Військова освіта. - 2017. - № 2(36). - С. 57-68.

6. Капосльоз Г. Деякі аспекти моніторингу наукового забезпечення функціонування та розвитку педагогічної системи вищого військового навчального закладу / Г. Капосльоз // Військова освіта. - 2015. - № 2. - С. 93-105.

7. Капосльоз Г. Досвід освоєння та використання наукових результатів у навчальних закладах та органах управління освітою в Україні та за кордоном / Г. Капосльоз, О. Мельниченко, Л. Левицька // Військова освіта. - 2019. - № 1(39) - С. 120-132.

8. Кучерявий А. Актуальні напрями та теми науково-педагогічних досліджень у контексті реформи Збройних Сил України / А. Кучерявий, І. Кузьмич, О. Мітягін // Військова освіта. 2016. - № 2(34). - C. 146-151.

9. Сафронов О. Організація наукової та науково-технічної діяльності у Збройних Силах України в особливий період / О. Сафронов, О. Прохоров, М. Полторак // Військова освіта. 2015. - № 2. - C. 211-220.

\section{REFERENCES}

1. Alimpiyev, A.M. (2014). Modeli i metody planuvannya ta upravlinnya naukovymy doslidzhennyamy. [Models and methods of planning and management of scientific researches]. Nauka i tekhnika Povitryanykh Syl Zbroynykh Syl Ukrayiny, 2(15), 173-176. (in Ukrainian).

2. Bakumenko R. Informatsiyno-analitychne zabezpechennya orhaniv viys'kovoho upravlinnya: stan, problem ta pidhotovky fakhivtsiv. [Information and analytical support for military authorities: the state, problems and training of specialists.] / R. Bakumenko // Viys'kova osvita. - 2019. - № 1(39). p. 8-16.

3. Boholib, T. Komertsializatsiia naukovykh rozrobok universytetiv. Upravlinnia ekonomikoiu: teoriia i praktyka. "Ekonomika Ukrainy". [Commercialization of scientific developments of universities. Economics Management: Theory and Practice. "Ukraine economy"] - 2014.- № 1, 33-50 p.

4. Hnidenko M. Sposib iyerarkhichnoho strukturuvannya informatsiynoho prostory navchalnoho protsesy. [Method of hierarchical structuring of the information space of the educational process] / $\mathrm{M}$. Hnidenko, O. Il'yin // Viyskova osvita. - 2017. - № 1(35). - p. 38-44.

5. Djubchuk R. Mistse ta rol' naukovykh doslidzhen' u zabezpechenni osvitn'oyi diyal'nosti vyshchoho viys'kovoho navchal'noho zaklady tekhnichnoho profilyu pidhotovky. [The place and role of scientific research in providing the educational activity of a higher military educational establishment with a technical training profile] / R. Djubchuk, G. Kaposloz, O. Rozumnyy // Viyskova osvita. - 2017. - № 2(36). - p. 57-68.

6. Kaposloz G. Deyaki aspekty monitorynhu naukovoho zabezpechennya funktsionuvannya ta rozvytky pedahohichnoyi systemy vyshchoho viys'kovoho navchal'noho zakladu. [Some aspects of monitoring the scientific support of the functioning and development of a pedagogical system of a higher military educational institution.] / G. Kaposloz // Viyskova osvita. - 2015. - № 2. - p. 93-105. 
7. Kaposloz G. Dosvid osvoennya ta vykorystannya naukovykh rezul'tativ u navchal'nykh zakladah ta orhanakh upravlinnya osvitoyu v Ukraine ta za kordonom. [Experience in mastering and using scientific results in educational institutions and education management bodies in Ukraine and abroad] / G. Kaposloz, O. Melnichenko, L. Levickaja // Viyskova osvita. - 2019. - № 1(39) - p. 120132.

8. Kucheryavyy A. Aktual'ni napryamu ta temy naukovo-pedahohichnykh doslidzhen u konteksti reform Zbroynykh Syl Ukrayiny [Current trends and topics of scientific and pedagogical research in the context of reform of the Armed Forces of Ukrain ] / A. Kucheryavyy, I. Kuz'mych, O. Mityahin // Viyskova osvita. - 2016. - № 2(34). - p. 146-151.

9. Safronov O. Orhanizatsiya naukovoyi ta naukovo-tekhnichnoyi diyal'nosti u Zbroynykh Sylakh Ukrayiny v osoblyvyy period. [Organization of scientific and scientific-technical activities in the Armed Forces of Ukraine in a special period] / O. Safronov, O. Prokhorov, N. Poltorak // Viyskova osvita. - 2015. - № 2. - p. 211-220.

\section{PЕЗЮМЕ}

Лариса Левицкая,

Национальный университет обороны Украины имени Ивана Черняховського

\section{Имплементация результатов научных исследований в высших военных учебных заведениях: подходы и способы оптимизации}

В статье рассмотрены существующие подходы и способы имплементации результатов научных исследований в образовательную деятельность высших военных учебных заведений, обобщен отечественный и иностранный опыт освоения, использования и коммерциализации научных результатов, определена связь прочесса имплементации результатов научных исследований в образовательную деятельность и потребностями, определяюшими уровень подготовки военных специалистов к практической деятельности в войсках (силах) и органах военного управления.

Ключевые слова: военные специалисты; высшие военные учебные заведения; имплементация; коммерциализация; научные исследования; подход; способы оптимизации.

\section{SUMMARY}

Larisa Levickaja,

National University of Defense of Ukraine named after Ivan Chernyakhovskyi

Implementation of the scientific researches results in high military educational institutions: approaches and methods of optimization

Abstract. The article gives a detailed analysis of the use of scientific achievements in the practice of educational activities of higher military education establishments.

Much attention is drawn to the opportunities which the perspective model of organizing the scientific support gives to the HMEE.

The main conclusion is that the development of the specific assessment techniques for the evaluation of the quality of the educational process and training of military specialists still requires further research.

Introduction. In the context of modernization of the national military education system, the use of scientific achievements in the practice of educational activities of higher military education establishments is one of the most important and necessary conditions for training the highly qualified military specialists. 
Purpose: The purpose of the article is to analyze the approaches and ways to optimize the process of implementation of research results into the activities of the higher military education establishments in connection to improving the evaluation of the quality of military specialists training.

Methods: Research methods are theoretical, analytical, using scientific sources for the creation and operation of information-analytical management systems.

Results. The perspective model of organization the scientific support to educational activity of the HMEE (higher military education establishments) gives the opportunity:

-to increase the scientific qualification of the pedagogical staff;

- to improve the methodological support of educational activities of the HMEE;

-to improve the research part of the educational and material base of the HMEE;

-to focus the main efforts on carrying out scientific researches aimed at the solution of problems relevant to educational activity of the HMEE, etc.

Conclusion. Active implementation of the results of modern scientific research into the educational process of the HMEE will allow to improve the approaches to the evaluation of the quality of the educational process and training of military specialists. An important issue in this context is to develop the specific assessment techniques, this requires further research.

Key words: military specialists; higher military educational establishments; implementation; commercialization; scientific achievements; modernization; ways to optimize. 